\title{
Effectiveness of intravenous clarithromycin followed by oral clarithromycin in acute exacerbation of asthma with respiratory tract infection
}

\author{
Wiwien Heru Wiyono, Risa Febriana, Faisal Yunus, Arifin Nawas, Menaldi Rasmin
}

\begin{abstract}
Abstrak
Penelitian kegunaan makrolid pada asma eksaserbasi menunjukkan bahwa di samping memiliki efek antimikroba, makrolid juga memiliki aktivitas sebagai imunomodulator. Penelitian ini bersifat kuasi-eksperimental untuk menilai efek klaritromisin yang diberikan secara intravena dilanjutkan terapi oral klaritromisin pada 37 pasien asma eksaserbasi akut yang disebabkan infeksi saluran napas selama periode Januari sampai dengan Desember 2005. Pasien asma akut ringan dan sedang yang memenuhi kriteria diberikan klaritromisin intravena $2 \times 500 \mathrm{mg}$ selama maksimal 5 hari dilanjutkan klaritromisin oral $2 \times 500 \mathrm{mg}$ selama 7 hari. Dilakukan evaluasi perbaikan klinis sesuai skor serangan asma, dan arus puncak ekspirasi (APE). Sesudah 10 hari, hasil pengobatan menunjukkan perbaikan signifikan perbaikan skor serangan asma dan APE pagi dan sore sebelum dan sesudah pengobatan pada 35 subjek yang diteliti, sedangkan hari sulih didapatkan kurang dari 3 hari pada 21 subjek dan 3-5 hari pada 14 subjek. Kuman yang paling banyak ditemukan adalah golongan S. $\beta$-haemolyticus dan Streptococcus sp. Disimpulkan bahwa pengobatan dengan klaritromisin intravena yang dilanjutkan secara oral dapat memberikan perbaikan gejala klinis dan nilai APE pada eksaserbasi asma akibat infeksi saluran napas. (Med J Indones 2007; 16:7-13)
\end{abstract}

\begin{abstract}
In addition to its antimicrobial activity, macrolides have an immunomodulatory effect that may be beneficial to patients with asthma. This quasi-experimental study aimed to determine the effect of intravenous clarithromycin followed by oral administration in 37 patients with acute exacerbations asthma caused by respiratory tract infection during January - December 2005. Patients with mild to moderate exacerbations of asthma with respiratory tract infection meeting the inclusion and exclusion criteria were given intravenous clarithromycin $2 \times 500 \mathrm{mg} /$ day for not more than 5 days and followed by oral clarithromycin $2 \times 500 \mathrm{mg} /$ day for 7 days. Outcome variables were improvement of clinical symptoms according to the asthma exacerbation score and peak expiratory flow rate (PEFR). After 10 days, treatment resulted significant improvement in total asthma exacerbation score and morning PEFR in 35 patients enrolled this project. Based on clinical improvement and laboratory findings, the number of days required for intravenous clarithromycin was less then 3 days for 21 subjects, $3-5$ days in 14 subjects. The most common causative pathogens were S. $\beta$-haemolyticus and Streptococcus sp. It was concluded that clarithromycin improved clinical symptoms and PEFR in exacerbation of asthma caused by respiratory tract infection. (Med J Indones 2007; 16:7-13)
\end{abstract}

Keywords: Claritromycin, asthma exacerbation, respiratory tract infection

Asthma is a respiratory inflammatory disease which may affect the quality of life and cause social or economic problems. ${ }^{1}$ In last three decades, the prevalence of asthma is rapidly rising in United States and many parts of the world. The International Study of Asthma and Allergy in Childhood, which studied the prevalence of asthma in 56 countries during 1990, found that prevalence ranged between 2-3\% in East Europe, Indonesia, Greek, Uzbekistan, India, and Ethiopia

Department of Pulmonology and Respiratory Medicine, Faculty of Medicine, University of Indonesia / Persahabatan Hospital, Jakarta, Indonesia and $20 \%$ in England, Australia and New Zealand. ${ }^{2}$ A study conducted by Yunus et al. in 2001 indicated that prevalence was $8.9 \%$ with a cumulative prevalence of 11.5 in East Jakarta Junior High School students aged 13-14 years. $^{3}$

The role of respiratory tract infection, especially viral infection, in the exacerbation of asthma is well-known, and occurs in an estimated $80 \%$ of patients. Recently, bacterial infection was also regarded as an important factor in the exacerbation of asthma. Common bacteria found in asthmatic patients are Haemophillus influenzae, Streptococcus pneumonia, Mycoplasma pneumoniae, Chlamydia pneumoniae, Klebsiella pneumoniae, Pseudomonas sp and Moraxella catarrhalis. ${ }^{4}$ 
Several studies have indicated that macrolides are wide spectrum antibiotics which may be given to asthma patient. Macrolides are active drugs against atypical bacteria, which are commonly found in asthma patient. In addition to their antimicrobial activity, they are also associated with muco-regulatory and anti-inflammatory activities. ${ }^{5-8}$ Clarithromycin, a macrolide, has an antiinflammatory effect through several mechanisms such as neutrophil migration, oxidative burst of phagocytes and anti-inflammatory cytokines production. ${ }^{9}$ The interaction as an antibiotic and the anti-inflammatory effect may increase airway responsiveness and improve clinical symptoms in asthma patients. ${ }^{10,11}$ Therefore, clarithromycin is expected to accelerate clinical improvement of asthma exacerbation caused by respiratory tract infection. To our knowledge, no study has ever been carried out on the effect of intravenous clarithromycin followed by oral administration in acute exacerbation of asthma patient with respiratory tract infection in Indonesia. The objective of this study was to evaluate the anti-microbial efficacy of clarithromycin in asthma exacerbation caused by respiratory tract infection.

\section{METHODS}

This is a quasi-experimental study conducted in respiratory ward of Persahabatan Hospital/Department of Pulmonology and Respiratory Medicine, Faculty of Medicine, University of Indonesia, Jakarta during January-December 2005. This study was approved by the Institutional Review Board/Independent Ethics Committee (IRB/IEC) of the Faculty of Medicine University of Indonesia. The subjects involved were 37 mild and moderate acute asthma patients with signs of respiratory tract infection.

Samples were obtained by consecutive sampling, where every eligible patient was included until the total amount was fulfilled. The inclusion criteria were mild to moderate acute exacerbation of asthma according to the 2004 GINA criteria. ${ }^{12}$ They were also diagnosed with respiratory tract infection, in keeping with the criteria of atypical pneumonia, male or female aged 12 to 65 years, able to take drugs, and willing to participate in the study for 10 days period by signing an informed-consent form. The exclusion criteria were allergy to clarithromycin, pregnant or breast-feeding, previously under treatment with antibiotics, patients with gastrointestinal disorder or malabsorption, patients with other pulmonary diseases such as tuberculosis, lung cancer, bronchiectasis, posttuberculosis obstruction syndrome and chronic obstructive pulmonary disease (COPD), and refusal to participate in this study. Patients were withdrawn from the study if they were unable to continue treatment. Patients were considered as failures in treatment if there was clinical exaggeration after the maximum 5 days of intravenous clarithromycin treatment or if mycobacteria (acid-fast bacilli) were found in their sputum.

The procedures for eligible subjects were as follows:

1. Sputum examination. Sputum, obtained by coughing, was put into a sterile bottle and sent to the laboratory for microorganism culture and resistance examinations on early observation (day 0 ).

2. Standard asthma treatment with intravenous aminophylline and non-steroid beta-2 agonist inhalation, or with steroid inhalation if previously under steroid treatment.

3. Clarithromycin skin-test.

4. Intravenous clarithromycin $2 \times 500 \mathrm{mg} /$ day; 500 $\mathrm{mg}$ clarithromycin was diluted with $10 \mathrm{cc}$ of sterile water. Subsequently, it was diluted with lactated ringer's solution and given by intravenous drip for a-6 hour period. Intravenous clarithromycin was given for not more than 5 days and then followed by oral clarithromycin 2 X $500 \mathrm{mg} /$ day for 7 days.

5. Microscopic sputum examination for acid-fast bacilli on days 1,2 , and 3 .

6. Blood leukocyte count on days 0 and 3.

7. Daily observation of body temperature, pulse rate, respiratory rate and PEFR.

8. Daily score evaluation to determine overall improvement of asthma. ${ }^{13,14}$

9. Recording adverse events of treatment.

Data was analyzed using Wilcoxon test (SPSS 10 statistical software).

\section{RESULTS}

Several limitatations must be considered in interpreting our findings. Among others, that the subjects were derived from only one hospital with a small number of subjects. There were 38 patients with 1 patient excluded due to positive for acid-fast bacilli (AFB). Table 1 showed there were more females than males. The youngest subject was 12 years-old and the oldest subject was 65 years-old. The most frequent level of education was secondary. Previous history of asthmaattack treatment indicated that most of the subjects used oral and inhalation beta- 2 agonist, followed by beta- 2 agonist and/or oral xanthine, and beta- 2 agonist inhalation. One subject (2.7\%) did not use either treatment. 
Previous history of asthma-controller drugs included 21 subjects (56.8\%) with no controller-drug, 12 subjects (32.4\%) with inhalation controller-drug and 4 subjects $(10.8 \%)$ with oral controller-drug. The most common asthma was moderate persistent asthma, followed by intermittent asthma. Only one subject had severe persistent asthma.

Table 1. Some demographic and clinical characteristics of subjects

\begin{tabular}{lcc}
\hline & $\mathrm{n}=37$ & $\%$ \\
\hline Gender & 11 & 29.7 \\
Male & 26 & 70.3 \\
Female & & \\
Education & 9 & 24.3 \\
Primary education & 23 & 62.2 \\
Secondary education & 5 & 13.5 \\
Tertiary education & & \\
Severity of exacerbation & 7 & 18.9 \\
$\quad$ Mild acute & 30 & 81.1 \\
Moderate acute & & \\
Severity of disease & 11 & 29.7 \\
Intermittent & 8 & 21.6 \\
Mild persistent & 17 & 45.9 \\
Moderate persistent & 1 & 2.7 \\
Severe persistent & & \\
Reliever & 1 & 2.7 \\
None & 11 & 29.7 \\
Oral & 5 & 13.5 \\
Inhalation & 20 & 54.1 \\
Oral and inhalation & & \\
Controller & 21 & 56.8 \\
None & 4 & 10.8 \\
Oral & 12 & 32.4 \\
Inhalation & \multicolumn{2}{c}{$43.89 \pm 14.59$} \\
Age (years) & & \\
\hline
\end{tabular}

\section{Initial data and observation}

As shown in Table 2, the mean total score for asthma attack in the initial observation was high. The mean morning and evening PEFR values were low and the mean leukocyte count in the initial observation was high.

\section{Microbiological observation}

Microbiological examination of sputum was conducted before treatment. Thirty subjects $(78.9 \%)$ had positive bacterial findings and 8 subjects (21.1\%) had negative bacterial findings. Twelve subjects (31.6\%) demonstrated 2 types of bacteria findings in their sputum. In all, there were 41 types of bacteria, with the bacterial pattern shown in Table 3.
Table 2. Some clinical conditions of subjects

\begin{tabular}{lccc}
\hline & Score & $\mathrm{n}$ & $\%$ \\
\hline Shortness of & 1 & 4 & 10.8 \\
breath & 2 & 32 & 86.5 \\
& 3 & 1 & 2.7 \\
Ability to talk & 1 & 14 & 37.8 \\
Consciousness & 2 & 23 & 62.2 \\
& 0 & 34 & 91.9 \\
Respiratory rate & 1 & 3 & 8.1 \\
& 2 & 30 & 81.1 \\
Chest retraction & 0 & 2 & 18.9 \\
& 1 & 33 & 5.4 \\
Wheezing & 2 & 2 & 89.2 \\
& 1 & 2 & 5.4 \\
Pulse rate & 2 & 35 & 5.4 \\
& 0 & 21 & 94.6 \\
& 1 & 15 & 56.8 \\
Morning PEFR & $107.6 \pm 47.6$ & 40.5 \\
Evening PEFR & $121.35 \pm 71.49$ & 2.7 \\
Total score & $10.14 \pm 1.56$ & \\
Leukocyte count & $14578.38 \pm 6793.63$ & \\
\hline
\end{tabular}

Table 3. Patterns of bacteria before treatment

\begin{tabular}{lcc}
\hline \multicolumn{1}{c}{ Microorganism } & $\mathrm{n}$ & $\%$ \\
Gram-negative & & \\
Klebsiella sp & 10 & 24.3 \\
P.aeruginosa & 6 & 14.6 \\
Acinetobacter sp & 4 & 9.7 \\
Citrobacter brachii & 1 & 2.4 \\
Gram-positive & & \\
Streptococcus pneumonia & 1 & 2.4 \\
Streptococcus $\alpha$ haemolyticus & 4 & 9.7 \\
Streptococcus $\beta$ haemolyticus & 5 & 12.2 \\
Streptococcus pyogenes & 4 & 9.7 \\
Streptococcus sp & 5 & 12.2 \\
Staphylococcus coagulae & 1 & 2.4 \\
Total of microorganism & 41 & 100 \\
\hline
\end{tabular}

\section{Bacteria susceptibility pattern}

Bacteria susceptibility pattern of Gram-positive bacteria against clarithromycin can be seen in Table 4 .

\section{Evaluation of respiratory rate improvement}

On initial observation, the mean respiratory rate was $28.0 \pm 3.7 / \mathrm{min}$. On days 1, 2, 3, and day 10 of observation, there was a decrease in mean respiratory rate $24.23 \pm 2.65 / \mathrm{min} ; 22.57 \pm 2.45 / \mathrm{min} ; 21.20 \pm 2.34 / \mathrm{min}$ and $18.91 \pm 1.48 / \mathrm{min}$, respectively. The difference was statistically significant $(\mathrm{p}=0.000)$. 
Table 4. Sensitivity patterns of bacteria

\begin{tabular}{lccc}
\hline \multicolumn{1}{c}{ Microorganism } & \multicolumn{3}{c}{ Sensitivity test of Clarithromycin } \\
\cline { 2 - 4 } & sensitive & intermediate & resistent \\
\hline Positive Gram & 0 & 0 & 1 \\
Streptococcus pneumonia & 4 & 0 & 0 \\
Streptococcus $\alpha$ haemolyticus & 3 & 0 & 2 \\
Streptococcus $\beta$ haemolyticus & 2 & 0 & 2 \\
Streptococcus pyogenes & 5 & 0 & 0 \\
Streptococcus sp & 1 & 0 & 0 \\
Staphylococcus coagulae & & & \\
\hline
\end{tabular}

\section{Evaluation of pulse rate improvement}

The pulse rate on initial observation was $96.97 \pm$ $10.55 / \mathrm{min}$. There was a decrease in the mean value between day 0 and days $1,2,3$ and 10, $91.76 \pm 7.15 / \mathrm{min}$; $88.7 \pm 8.50 / \mathrm{min} ; 86.43 \pm 5.32 / \mathrm{min} ; 82.76 \pm 4.51 / \mathrm{min}$, respectively. The difference was found to be statistically significant $(\mathrm{p}=0.000)$.

\section{Evaluation of PEFR improvement}

The mean morning and evening PEFR values on days $1,2,3$ of observation, the difference was statistically demonstrated to be significant $(\mathrm{p}=0.000)$ (data not shown).

\section{Evaluation of asthma total score and leukocyte count improvement}

Table 5 showed a decrease in total asthma-attack score in 35 subjects observed during day 0 to day 3 of hospitalization; the difference was statistically significant $(\mathrm{p}=0.000)$. From days 0 to 3 of observation, there was a decrease in leukocytes count, except for 2 subjects, who should receive other treatment. This decrease in leukocytes count was statistically significantly $(\mathrm{p}=0.000)$.

Table 5. Total mean score of asthmatic attack

\begin{tabular}{ccc}
\hline & Mean \pm SD & p value \\
\hline Day 0 & $10.14 \pm 1.53$ & \\
Day 1 & $7.35 \pm 1.81$ & 0.000 \\
Day 2 & $5.55 \pm 2.1$ & 0.000 \\
Day 3 & $3.73 \pm 2.01$ & 0.000 \\
Leukocyte count during observation & \\
Day 0 & $14578.38 \pm 6793.63$ & \\
Day 3 & $9602.70 \pm 2950.093$ & 0.000 \\
\hline
\end{tabular}

Wilcoxon test: compared to day 0

\section{Changes in body temperature}

The mean body temperature in was initially $37.8 \pm 0.87^{\circ} \mathrm{C}$ which decreased on days 1,2 and $3,36.65 \pm 0.47^{\circ} \mathrm{C}$;
$36.59 \pm 0.46^{\circ} \mathrm{C}$ and $36.7 \pm 0.59^{\circ} \mathrm{C}$, respectively. The difference was statistically significant $(\mathrm{p}=0.000)$.

\section{Duration of intravenous therapy}

Based on clinical observation through asthma-attack scoring, leukocytes count, gastrointestinal function, and hemodynamic stability, intravenous antibiotic treatment was switched to oral treatment after a maximum of 5 days in 35 subjects. The mean duration for intravenous antibiotic treatment was $2.5 \pm 0.64$ days.

\section{Evaluation of final treatment result}

Evaluation of final treatment results conformed to clinical response based on asthma-attack score and laboratory findings in 37 subjects. Favorable clinical response was found in 34 subjects $(92 \%)$, poor clinical response was found in 1 subject $(2.7 \%)$ and treatment failure in 2 subjects (5.4\%).

\section{Unexpected Adverse Events}

The most common unexpected adverse events were erythema at the injection site in 16 subjects (43.2\%), followed by tenderness during intravenous drug administration in 10 subjects (27\%), and headache in 1 patient $(2.7 \%)$. The pain was still tolerable and therefore no drug substitution was conducted for these symptoms.

\section{DISCUSSION}

The are some limitations that must be considered in interpretating of our study. Among others, we had a small number of subjects and came from one hospital. There were 37 subjects involved in this study, 30 subjects had moderate acute asthma and 7 had mild acute asthma as defined by the 2004 GINA classification on the severity of asthma attack. ${ }^{12}$ The number of female subjects was greater than males. 
This finding was similar to previous studies, which found that there were more female patients visiting emergency room because of asthma attack. ${ }^{13-15}$ Female asthma patients were higher in numbers compared to male patients, because they undergo a more frequent decrease in $\mathrm{VEP}_{1} \%$ and PEFR as a consequence of hormonal changes during menstruation, and females were more commonly sensitized by environment exposure. Female patients were also more likely to be hospitalized because they frequently experience viral infections, exposure to nitrogen oxide, household irritants and aeroallergens. ${ }^{16}$ In this study, there were more subjects with moderate persistent asthma compared to intermittent or mild persistent asthma. This finding differed from a previous study on severe acute asthma, which found more intermittent asthma subjects than subjects with persistent asthma. ${ }^{14}$

The mean pulse rate was statistically significant decreased compared with the initial observation. The mean pulse rate in this study was found to be lower than in a previous study, since the severity of acute asthma was greater than in this study, which meant that the load on the heart was not as great. ${ }^{14}$

The mean morning PEFR value on initial observation in this study was higher than in a previous study, where the subjects suffered from severe acute asthma. ${ }^{14}$ Initial observations in an exacerbation of acute asthma found about $55 \%$ of the patients had a PEFR value lower than $40 \%$ of the prediction value while about $20 \%$ of the patients had a PEFR value between $40-60 \%$ of prediction. ${ }^{17}$ Clinical parameters correlated to airway obstruction used in this study were PEFR value, respiratory accessory muscle retraction, wheezing, and shortness of breath, which are similar to previous studies. ${ }^{13,14}$ Greater airway obstruction in asthma may cause increased airflow resistance 5 times greater than the normal value. Decrease inspiration airflow was lower than expiration, which will cause increased respiration in inspirational phase. As a result, there was decreased dynamic pulmonary compliance, with more active respiratory muscle work.

Most of subjects in this study had increased leukocyte count and increased body temperature $(37.8 \pm 0.87)$ on initial observation. Subsequent observations showed a decrease in leukocyte count and body temperature. Increased leukocyte count and body temperature support the hypothesis that there is an exacerbation of infection in these subjects, while decreased body temperature and leukocyte count after treatment may be caused by the antimicrobial effect of clarithromycin.
Because of the expense, serological examination was not conducted in this study. Atypical pneumonia was therefore established by combining previous clinical symptoms, infection symptoms, and physical examination, with laboratory findings.

Microbiological examination was limited to aerobic Gram-positive and Gram-negative bacteria, while anaerobic, atypical bacteria and $H$. influenzae were not examined since serological examination and special bacterial media were needed. In addition, atypical bacteria especially $C$. pneumoniae is commonly found as concomitant pathogen with other infectious pathogen such as S. pneumoniae. Microbiological examination revealed 41 types of bacteria. The most common Gram-positive bacteria were $S$. $\beta$ haemolyticus and Streptococcus sp followed by $S$. pyogenes, $S . \alpha$ haemolyticus, $S$. pneumoniae and $S$. coagulae. The most commonly found Gram-negative bacteria was Klebsiella $s p$, followed by P. aeruginosa, Acinetobacter sp. The least common was Citrobacter brachi. In this study, the types of Gram-positive bacteria were almost equal to Gram-negative bacteria. Results from other studies on lower respiratory tract infection (LRTI) demonstrated that the microorganism pattern in acute exacerbation of chronic pulmonary disease was dominated by aerobic Gram-negative bacteria and followed by Grampositive bacteria. ${ }^{18}$ Pseudomonas aeruginosa was one of Gram-negative bacteria commonly found in this study. Mucoid and non-mucoid fixed colonization of $P$. aeruginosa bacteria was found in most chronic pulmonary disease such as diffuse panbronchiolitis (DPB), cystic fibrosis, etc. ${ }^{9}$ Mucoid Pseudomonas aeruginosa will produce a bio-film which functions as an antigen, inducing an antigen-antibody reaction on the airway surface, making bacterial eradication difficult. Macrolides treatment will cause a decrease in immune complex. Consequently, it will improve the clinical condition of patients with DBP. In addition, as another study revealed, clarithromycin administration may decrease $P$. aeruginosa adherence on cells. ${ }^{9}$

The results of microbial susceptibility test revealed 5 subjects (30\%) were resistant to clarithromycin. Some studies indicated relatively less resistance against macrolides. ${ }^{19}$ The bacteria resistant to clarithromycin in that study included $S$. pneumoniae and $S$. pyogenes which is an extra-cellular bacteria found in pulmonary tissue or epithelial lining fluid (ELF). There was a higher concentration of clarithromycin in ELF and macrophages compared to plasma 24 hours after drug administration. In addition, there was an inconsistency between the results of in vitro resistance test and favorable clinical response to clarithromycin, which is 
probably caused by low-resistance strain bacteria. ${ }^{19}$ This was probably the reason why that although there was resistance to clarithromycin, favorable clinical response based on asthma-attack score and laboratory findings was achieved. There were 34 subjects (92\%) with have excellent results, one subject $(2.7 \%)$ with poor results, and failures in two subjects (5.4\%), probably due to nosocomial infections. The clarithromycin efficacy is correlated to its ability to be actively accumulated by tissue fluid and macrophages. The clarithromycin concentration in pulmonary tissue is 10 times higher compared to its serum concentration. Consequently, clarithromycin is effective against most respiratory tract pathogen.

In addition, macrolides may also reduce bronchoconstriction through inhibition of cholinergic response in the airway smooth muscle and it may also reduce endotelin-1 release, which has been known as potent bronchoconstrictor. ${ }^{9}$ In vitro, macrolides is known to be effective against various bacteria such as Streptococcus, $H$. influenzae, $M$. catarrhalis and atypical bacteria. For $H$. Influenzae, clarithromycin and azithromycin are more effective compare to erythromycin and dirithromycin. Macrolides (azithromycin and clarithromycin) are good agents for empirical therapy in community acquired pneumonia (CAP) because it deals well with almost all CAP bacterial pathogen especially the atypical bacteria which is commonly found in chronic inflammatory respiratory diseases such as asthma and COPD. Furthermore there is usually some difficulty in differentiating the etiology (for example atypical bacteria vs S. pneumoniae) in CAP only from clinical symptoms and radiology examination. $^{19}$

The most common unexpected adverse event found in this study was erythema at the injection site followed by tenderness during intravenous administration and headache. This unexpected adverse event in intravenous clarithromycin administration was probably due to the acidity of clarithromycin. In order to reduce the pain, sterile water was added to dilute the clarithromycin powder. These adverse events did not lead to drug discontinuation.

\section{CONCLUSION}

This study found that intravenous clarithromycin administration followed by oral administration provided clinical improvement in 37 mild to moderate acute asthma patients with respiratory tract infection.

\section{Acknowledgment}

Parts of this clinical trial were supported by an unrestricted grant from PT Abbott Indonesia.

\section{REFERENCES}

1. Martin JR, Kraft M, Chu HW, Berns EA, Cassell GH. A link between chronic asthma and chronic infection. J Allergy Clin Immunol. 2001;107:595-601.

2. Woodruff PG, Fahy JV. Asthma: prevalence, pathogenesis and prospects for novel therapies. JAMA. 2001;286:395-8.

3. Yunus F, Antaria R, Rasmin M, Mangunnegoro H, Jusuf A, Bachtiar A. Asthma prevalence among high school students in East Jakarta, 2001 based on ISAAC questionnaire. Med J Indones. 2003;12:178-86.

4. Hudgel DW, Langston L, Selner JC, McIntosh K. Viral and bacterial infections in adult with chronic asthma. Am Rev Respir Dis. 1979; 20:393-7.

5. Gotfried $\mathrm{MH}$. Macrolides for the treatment of chronic sinusitis, asthma and COPD. Chest. 2004;125:52S-9S.

6. Rubin BK, Henke MO. Immunomodulatory activity and effectiveness of macrolides in chronic airway disease. Chest. 2004;125:70S-8S.

7. Tagaya E, Tamaoki J, Kondo M, Nagai A. Effect of a short course clarithromycin therapy on sputum production in patients with chronic airway hypersecretion. Chest. 2002;122:213-8.

8. Spahn JD, Fost DA, Covar R, Martin RJ, Brown EE, Szefler SJ, et al. Clarithromycin potentiates glucocorticoid responsiveness in patients with asthma: result of a pilot study. Ann Allergy Asthma Immunol. 2001;87:501-5.

9. Jaffe A, Bush A. Anti-inflammatory effects of macrolides in lung disease. Pediatr Pulmonol. 2001; 31:464-73.

10. Amayasu H, Yoshida S, Ebana S, Yamamoto Y, Nishikawa T, Shoji T, et al. Clarithromycin suppress bronchial hyperresponsiveness associated with eosinophilic inflammation in patients with asthma. Ann Allergy Asthma Immunol. 2000;84:594-8.

11. Garey KW, Rubinstein I, Gotfried M, Kahn IJ, Varma S, Danziger LH. Long-term clarithromycin decreases prednisone requirements in elderly patients with dependent asthma. Chest. 2000;118:1826-7.

12. National Institute of Heart. Risk Factors. In: Global initiative for asthma. Bethesda: National Institute of Health; 2004. p.28-37.

13. Susanti F, Yunus F, Giriputro S, Mangunnegoro H, Jusuf A, Bachtiar A. Efikasi steroid nebulisasi pada asma akut berat dibandingkan dengan steroid intravena. Maj Kedok Indones. 2002;2:247-54

14. Sari A, Yunus F, Wiyono WH, Jusuf A, Hupudio A. Efikasi flutikason propionate nebulisasi pada serangan asma akut berat dibandingkan dengan metilprednisolon intravena (masa pengamatan 6 jam). Maj Kedokt Indones. 2005; 55:463-71.

15. Rodrigo GJ, Rodrigo C, Hall JB. Acute asthma in adults. A review. Chest. 2004;125:1081-102.

16. Scicchilone N, Messina M, Battaglia S, Catalano I, Bellia V. Airway hyperresponsiveness in the elderly: prevalence and clinical implications. Eur Respir J. 2005;25:364-75. 
17. Kotaru C, McFadden ER. Acute exacerbations of asthma. In: Barnes PJ, Drazen JM, Rennhard S, Thomson NC, editors. Asthma and COPD. Basic mechanisms and clinical management. North Yorkshire:Academic Press; 2002.p.691-75.

18. Mangunnegoro H, Hudoyo A, Yunus F. Efektivitas ofloxacin dosis tunggal pada infeksi saluran napas bawah. In:
Naskah lengkap simposium ofloxacin: Uji klinis ofloxacin pada berbagai penyakit infeksi. Jakarta, November 1992.

19. File TM, Tan JS. International guidelines for the treatment of community-acquired pneumonia in adults. The role of macrolides. Drugs. 2003; 63:181-205. 
